Arq. Bras. Med. Vet. Zootec., v.67, n.1, p.89-93, 2015

\title{
Tibial osteosynthesis in a guinea pig (Cavia porcellus)
}

\author{
[Osteossíntese de tíbia em um cobaio (Cavia porcellus)] \\ A.S. Macedo ${ }^{1}$, M.A. Goulart ${ }^{2}$, M.M. Alievi ${ }^{2}$, V.S. Mombach ${ }^{2}$, Í.S. Dal-Bó ${ }^{3}$, \\ M.S. Mucillo ${ }^{2}$, R.B. Silva ${ }^{4}$, B.W. Minto ${ }^{1}$ \\ ${ }^{1}$ Faculdade de Ciências Agrárias e Veterinárias - Unesp-Jaboticabal - Jaboticabal, SP \\ ${ }^{2}$ Faculdade de Veterinária (Favet) - UFRGS - Porto Alegre, RS \\ ${ }^{3}$ Faculdade de Medicina Veterinária e Zootecnia - USP - São Paulo, SP \\ ${ }^{4}$ Hospital Veterinário do Batalhão de Polícia do Exército de Brasília - BPEB - Brasília, DF
}

\begin{abstract}
A guinea pig was presented with left pelvic limb lameness after unknown trauma. Radiographs revealed complete oblique diaphyseal fracture of the distal third of the left tibia and fibula. The guinea pig was treated surgically with an intramedullary pin. The day after surgery the guinea pig was using the limb comfortably (grade 1/5 lameness). Callus formation was obtained 21 days after surgery without complications.
\end{abstract}

Keywords: wild animals, Kirschner wires, tibia, fracture

\section{RESUMO}

Um cobaio foi atendido com claudicação de membro pélvico esquerdo após trauma desconhecido. Radiografias revelaram fratura completa oblíqua da diáfise do terço distal da tíbia e fíbula esquerdas. $O$ cobaio foi tratado cirurgicamente com um pino intramedular. No dia seguinte à cirurgia, o paciente utilizava o membro confortavelmente (grau 1/5 de claudicação). Calo ósseo foi obtido 21 dias após a cirurgia, sem complicações.

Palavras-chave: animais silvestres, fios Kirschner, tíbia, fratura

\section{INTRODUCTION}

Guinea pigs (Cavia porcellus) are South American hystricomorph rodents, monogastric herbivores. They have stocky bodies, delicate short limbs with fragile bones and no tails (Quesenberry and Carpenter, 2011). Because they are active and curious, they often suffer traumas when exploring the environment around them. This implies the occurrence of injuries such as diaphyseal tibial fractures, which are often oblique, spiral or fragmentary and can sometimes be open fractures due to the lack of soft tissue around the bone (Johnson and Hulse, 2002). The anatomical position of the tibia reflects a variety of techniques for fracture repair, such as bandages, intramedullary pins, screws, cerclage wires, plates and external skeletal fixators (Denny and Butterworth, 2006). This paper reports the case of a complete diaphyseal fracture of the distal third shaft on the left tibia and fibula in a guinea pig treated surgically with an intramedullary pin.

\section{CASE REPORT}

A 3-month-old male guinea pig with bodyweight of $0.482 \mathrm{~kg}$ was presented to the Veterinary Teaching Hospital of the Federal University of Rio Grande do Sul (HCV-UFRGS) with a 2-day history of left pelvic limb lameness after unknown trauma. The guinea pig was eating and drinking well. Physical examination was unremarkable and orthopedic examination presented grade $3 / 5$ left hind limb lameness. 
Palpation revealed swelling, instability, crepitus and pain of the third shaft of the left tibia. Fracture was suspected. Conscious radiographs of the guinea pig were manually taken providing craniocaudal and mediolateral views of the left tibia (Figure 1-A and B). Complete oblique diaphyseal fracture of the distal third of the left tibia and fibula were diagnosed.

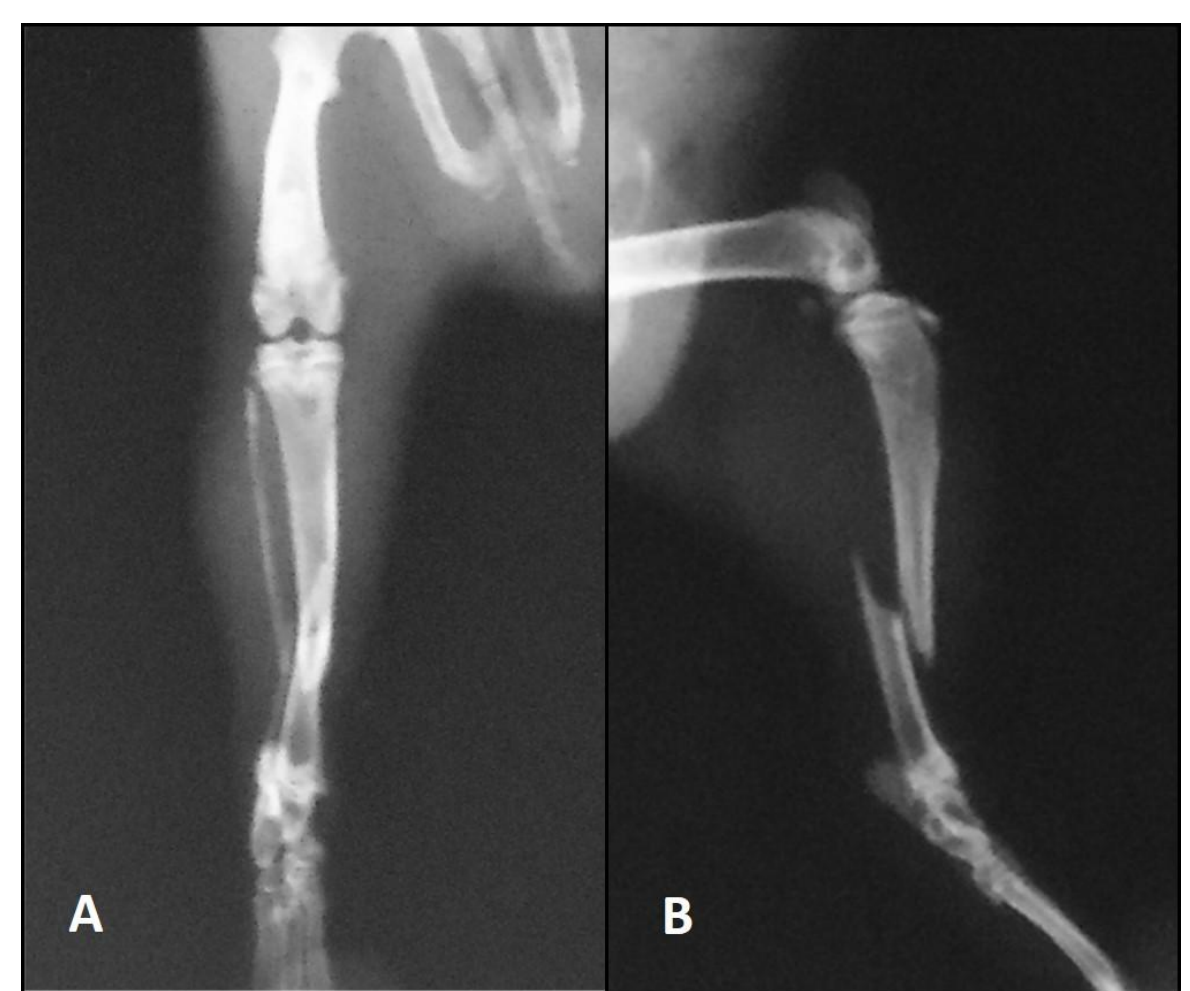

Figure 1. A - Craniocaudal preoperative radiographic view of the left tibia of the Cavia porcellus showing a complete oblique diaphyseal fracture of the distal third of the left tibia. B - Mediolateral preoperative radiographic view of the left tibia of the Cavia porcellus.

Surgical treatment was chosen. Intramuscular (IM) injection of ketamine hydrochloride $(15 \mathrm{mg} / \mathrm{kg})$ associated with butorphanol $(1 \mathrm{mg} / \mathrm{kg})$ was used as premedication. The patient was induced and maintained with isoflurane vaporized in $100 \%$ oxygen via mask (Figure 2 A). Epidural block was performed with lidocaine $(0,25 \mathrm{~mL} / \mathrm{kg})$ through the insertion of a 25 gauge 1.5 inch needle (Figure $2-\mathrm{B}$ ). The patient was then placed in right lateral recumbency, clipped and aseptically prepared for surgery with chlorhexidine gluconate $0.2 \%$. Pulse oximetry and pulse rate were continuously monitored during surgery (Figure $2-\mathrm{A}$ ). A medial approach was made to the shaft of the left tibia through the skin and subcutaneous tissues and the fracture site was identified. A $1.2 \mathrm{~mm}$ Kirschner wire (K-wire) was inserted in a retrograde fashion (Figure 3) into the proximal fragment, the fracture was reduced and the pin was advanced into the distal fragment and cut as not to damage the articular cartilage and ligaments of the knee. Once verified the stability of the fracture, the site was copiously lavaged with warm sterile saline. The subcutaneous tissue was apposed with 4-0 poliglactine 910 in a simple continuous pattern and the skin was sutured with 4-0 polyamide in a simple interrupted pattern.

Radiographs revealed good apposition and reduction of the fracture although the tip of the pin was protruding into the articular space (Figure $4-\mathrm{A}$ and B). Postoperative treatment consisted of subcutaneous (SC) meloxicam $(0,1 \mathrm{mg} / \mathrm{kg})$, single dose after surgery, dipyrone $(12 \mathrm{mg} / \mathrm{kg}) \mathrm{IM}$, single dose after surgery, tramadol hydrochloride $(3 \mathrm{mg} / \mathrm{kg}$ ) TID for 3 days and oral enrofloxacin $(10 \mathrm{mg} / \mathrm{kg})$ BID for 7 days. 


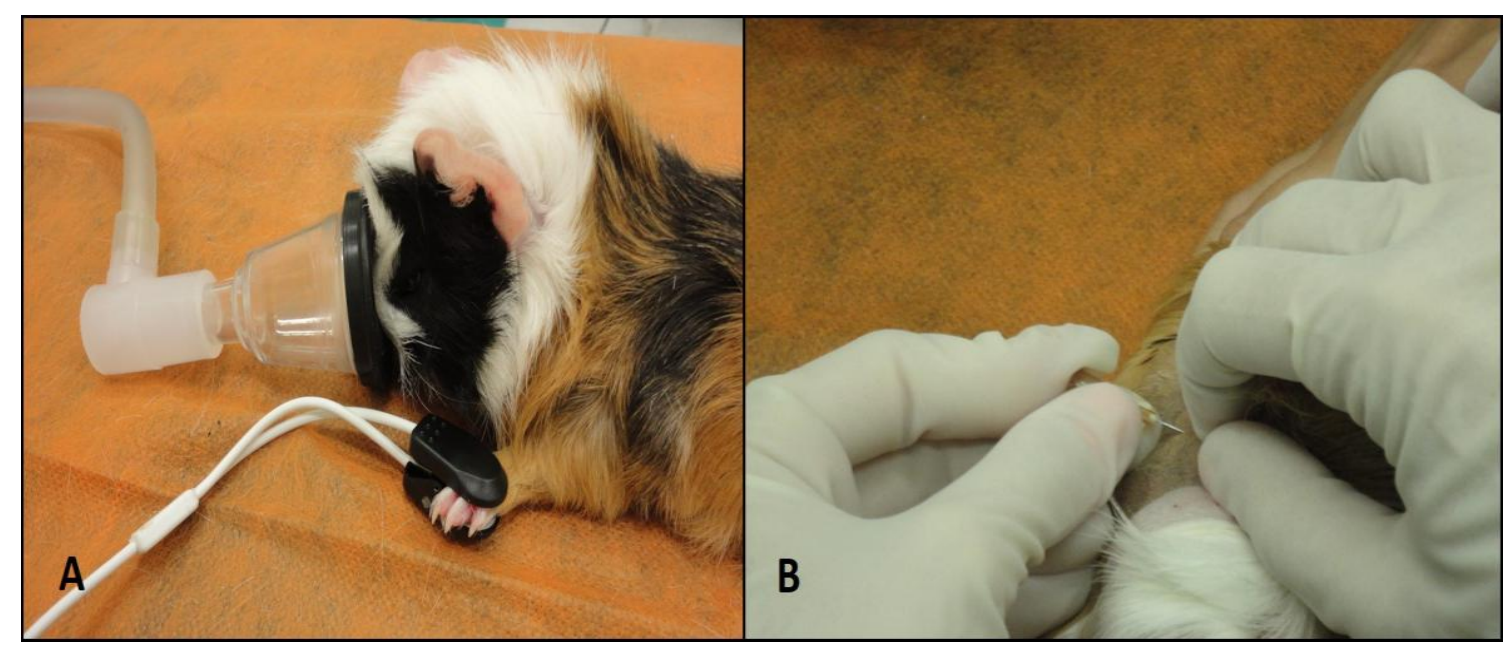

Figure 2. A - Image from anesthetic induction of the Cavia porcellus with a tight-fitting facemask connected to the breathing and anesthetic system. It is possible to notice the pulse and oximetry sensor attached to the left forelimb. B - Image of the insertion of a 25 gauge 1.5 inch needle for placement of epidural block on the patient.

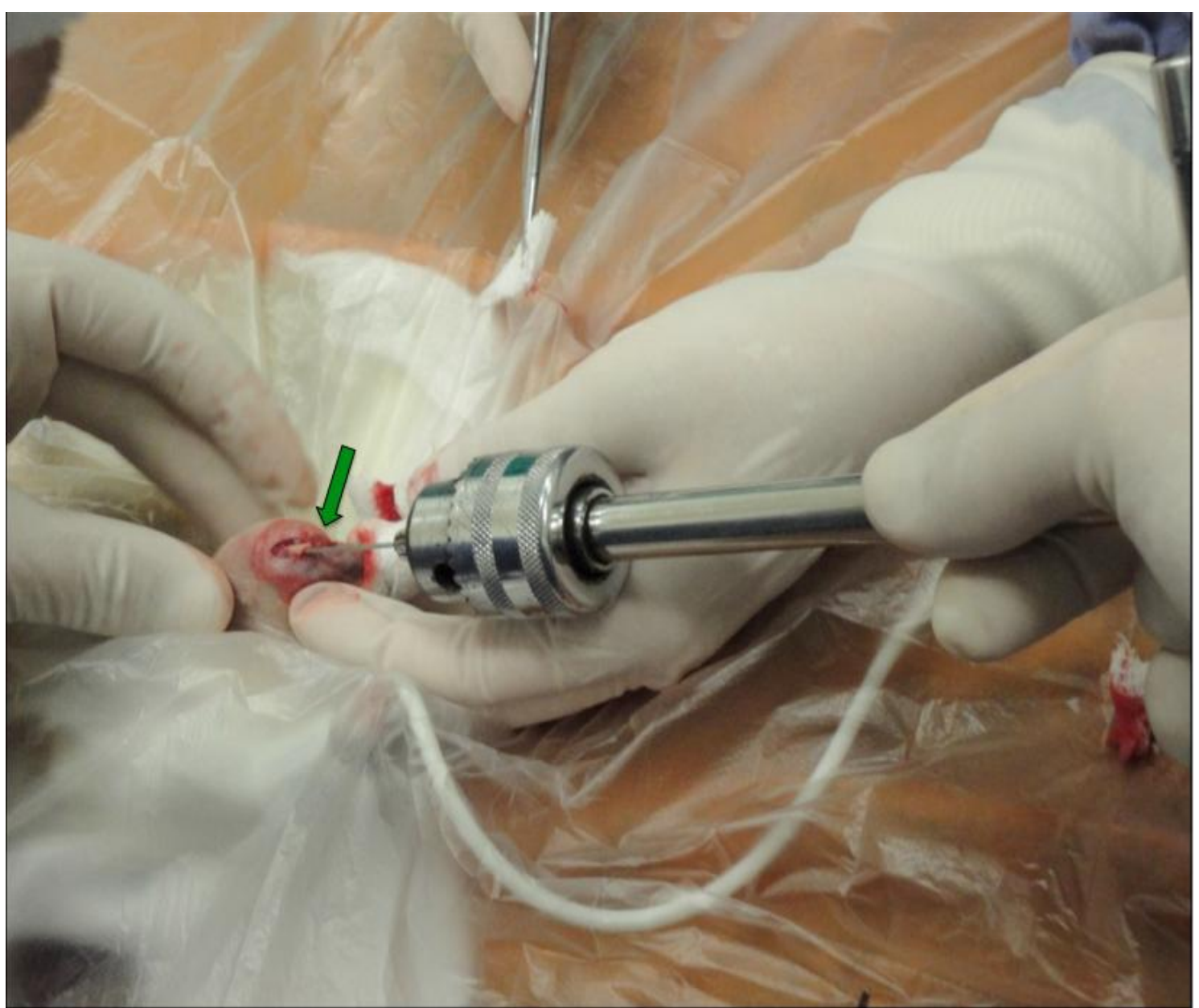

Figure 3. Transoperative image of the left tibial osteosynthesis of the Cavia porcellus. Note a K-wire insertion into the proximal fragment of the tibia (arrow). 


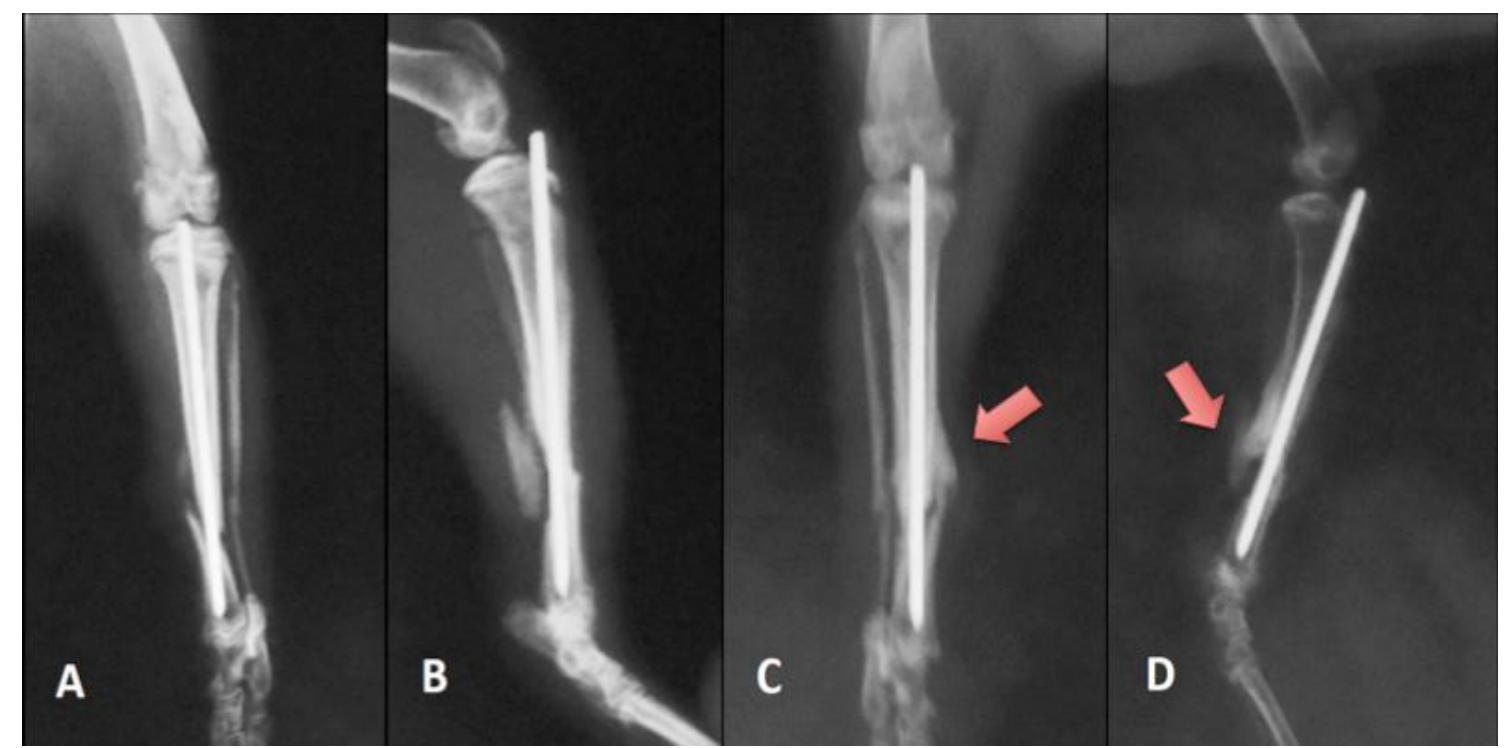

Figure 4. Postoperative radiographs of the left tibia of the Cavia porcellus. A - Immediate craniocaudal postoperative radiograph displaying acceptable fracture reduction; B - Immediate mediolateral postoperative radiograph. Note the proximal tip of the pin is longer than desirable and protrudes into the joint; $\mathrm{C}$ - 21 days postoperative craniocaudal radiograph, the pin has not migrated. Note callus formation (arrow); D - 21 days postoperative mediolateral radiograph. It is possible to observe callus formation (arrow).

The day after surgery the guinea pig was comfortably using the operated limb (grade 1/5 lameness); its usual appetite was regained and it was defecating normally. The patient was discharged with instructions for suture dressing and cage rest. One week after surgery the suture was removed. On the $21^{\text {th }}$ day after surgery the patient presented neither lameness nor pain at palpation; radiographs displayed good reduction and alignment of the fracture with evident bone healing and callus formation (Figure $4-\mathrm{C}$ and D). The pin had not migrated and wasn't disturbing normal limb movement. The patient did not return for further radiographs.

\section{DISCUSSION}

The type of fixation chosen has been described in guinea pigs for treatment of femoral fractures using the pin alone (Periat, 2008) or in association with polydioxanone cerclage (Aguiar et al., 2013). The tibia of a guinea pig is a long, straight bone with little soft tissue covering. It is longer than the femur and the fibula is virtually nonexistent (Quesenberry and Carpenter, 2011). The bones of guinea pigs are thin and fragile and surgical repair can be difficult. Nevertheless in this particular case the surgical procedure encountered no difficulties. Surgery was a good way to allow early limb usage; soft, padded bandages and lateral splints usually do not provide adequate stability for fractures to heal (Hoefer, 1994) and were not considered for this case. Surgically repairing the fracture with either wire or external fixators is recommended (Lorinson et al., 1996) but in this case the pin was an adequate choice due to the type of fracture (Brinker et al., 1999). An intramedullary $\mathrm{K}$-wire can be enough to fill almost the entire medullary canal resulting in a greater stabilizing effect and alignment of the bone segment due to the intimate contact of the pin with the surrounding bone cortex (Denny and Butterworth, 2006). Although authors suggest performing normograde pin insertion, we opted for a retrograde technique due to the patient's limited size. It has been reported that directing a retrograde pin in a craniomedial direction on dog tibias can produce an exit point very close to the proper entrance point for normograde insertion (Dixon et al., 1994).

Guinea pigs are active animals and it is essential to limit mobility by placing the animal in a small cage during the postoperative period (Quesenberry and Carpenter, 2011) so this was 
recommended for this patient. Radiographic callus formation was evident in 21 days, compatible with normal fracture healing (Piermattei et al., 1997) and consistent with other reports (Aguiar et al., 2013) and even other rodent species (Keller et al., 1987). Nonunion is a possible outcome when the necessary rest is not done (Quesenberry and Carpenter, 2011), fortunately this was not the case.

Pre medicating the patient is recommended to allow a smooth anesthetic induction (Longley, 2008) and the anesthetic protocol was satisfactory. Premedication and maintenance of anesthesia did not encounter any complications. The overall anesthetic related death risk for guinea pigs is $3.8 \%$. This is likely due to perioperative diseases involving respiratory, digestive, and fluid balance disorders and fewer veins easily accessible for catheterization than bigger mammals (Brodbelt et al., 2008). Intubation was not performed since it is not easily executed in such a small patient and can be more demanding than other species (Brodbelt et al., 2008); anesthesia was maintained with a tight-fitting facemask connected to the breathing system, as suggested by other studies (Longley, 2008). Epidural block has been described before in guinea pigs with possible association with hindlimb motor impairment, ataxia and loss of the placing reflex (Eisele et al., 1994). In this case this procedure provided proper anesthesia without complications. Sciatic and femoral nerve block has been described for femoral fracture in a guinea pig (Aguiar et al., 2013). Postoperative analgesia was achieved with a nonsteroidal antiinflammatory drug (NSAID) and an opioid, without eventualities. It is crucial to recognize pain as early as possible so it can be adequately treated before the onset of adverse disease effects (Longley, 2008).

\section{CONCLUSION}

With the recent popularity of guinea pigs in the role of domestic pets there is an increase on the demand for specialized veterinary services. Fractures are not rare in restless and curious animals such as guinea pigs. Surgical repair is recommended and resulted in a good outcome on this case. Conservative management was not considered due to the nature of the fracture and the poor compliance with bandage application in a patient of wild nature.

\section{REFERENCES}

AGUIAR, J.; MOGRIDGE, G.; HALL, J. Femoral fracture repair and sciatic and femoral nerve blocks in a guinea pig. J. Small Anim. Pract., v.54 , p.1-5, 2013. Disponível em: <http://onlinelibrary.wiley.com/doi/ 10.1111/jsap.12033/pdf> Acessado em: 14 fev. 2014.

BRODBELT, D.C.; BLISSITT, K.J.; HAMMOND, R.A. et al. The risk of death: the confidential enquiry into perioperative small animal fatalities. Vet. Anaesth. Anal., v.35, p.365-373, 2008.

DENNY, H.R.; BUTTERWORTH, S.J. Opções no tratamento das fraturas. In: DENNY H.R., BUTTERWORTH S.J. Cirurgia ortopédica em cães e gatos. 4.ed. São Paulo: ROCA, 2006. p.67-102.

DIXON, B.C.; TOMLINSON, J.L.; WAGNER-MANN, C.C. Effects of three intramedullary pinning techniques on proximal pin location and articular damage in the canine tibia. Vet. Surg., v.23, p.448-455, 1994.

EISELE, P.H.; KAAEKUAHIWI, M.A.; CANFIELD, D.R. et al. Epidural catheter placement for testing of obstetrical analgesics in female guinea pigs. Lab. Anim. Sci., v.44, p.486-490, 1994.

HOEFER, H.L. Chinchillas. Vet. Clin. North. Am. Small Anim. Pract., v.24, p.103-111, 1994.

JOHNSON, A.L.; HULSE, D.A. Fundamentals of orthopedic surgery and fracture management. In: Fossum, T.W. Small Anim. Surg.. 2.ed. ST. Louis: Mosby, 2002. p. 821-900.

KELLER, J.; BIINGER, C.; ANDREASSEN, T.T. et $a l$. Bone repair inhibited by indomethacin. Effects on bone metabolism and strength of rabbits osteotomies. Acta Orthop. Scand., v.58, p.379-383, 1987.

LONGLEY, L.A. Anaesthesia of Exotic Pets. Philadelphia: Saunders/Elsevier, 2008. p. 59-84.

LORINSON, D.; GRESSL, H.; IMMLER, R. Fracture treatment in rabbits, guinea pigs and chinchillas using an external fixator. Wien Tierarztl. Monat., v.83, p.232-237, 1996.

PERIAT, J. Femoral fracture repair in two guinea pigs. Exotic DVM, v.10, p.3, 2008.

PIERMATTEI, D.L.; FLO, G.L.; DECAMP, C.E. Fractures of the Tibia and Fibula. In: BRINKER, W.O.; PIERMATTEI, D.L.; FLO, G.L. Handbook of Small Animal Orthopedics and Fracture Treatment. 3.ed. Philadelphia: SAUNDERS, 1997. p.581-606.

QUESENBERRY K.; CARPENTER J.W. Ferrets, rabbits and rodents: Clinical medicine and surgery. Philadelphia: Elsevier, 2011. p.295-310. 